\title{
PERLINDUNGAN NEGARA TERHADAP DANA SIMPANAN NASABAH PADA PERBANKAN
}

\author{
ANDREW SHANDY UTAMA \\ Fakultas Hukum Universitas Lancang Kuning \\ e-Mail: andrew.fh.unilak@gmail.com \\ RAI IQSANDRI \\ Fakultas Hukum Universitas Lancang Kuning \\ e-Mail: andrew.fh.unilak@gmail.com
}

\begin{abstract}
ABSTRAK
Bank adalah lembaga keuangan yang kegiatan usahanya yaitu menghimpun dana dari masyarakat, menyalurkan dana kepada masyarakat, dan memberikan pelayanan jasa keuangan. Salah satu kegiatan utama perbankan adalah menghimpun dana dari masyarakat dalam bentuk tabungan, deposito, dan giro. Masyarakat menyimpan dananya di bank karena percaya bahwa keamanan dananya tersebut akan jauh lebih terjamin daripada menyimpannya di dalam rumah. Menurut Kitab Undang-undang Hukum Perdata, dana nasabah yang disimpan di bank tidak termasuk ke dalam kelompok piutang yang diistimewakan apabila sebuah bank dinyatakan pailit. Permasalahan yang akan dibahas dalam penelitian ini adalah bagaimanakah perlindungan negara terhadap dana simpanan nasabah pada perbankan yang mengalami kepailitan? Metode yang digunakan dalam penelitian ini adalah penelitian hukum normatif dengan menggunakan pendekatan peraturan perundang-undangan. Sumber data yang digunakan dalam penelitian ini adalah data sekunder, yaitu data yang diperoleh dari peraturan perundang-undangan, jurnal-jurnal ilmiah, dan literatur hukum. Teknik pengumpulan data yang digunakan dalam penelitian ini adalah studi kepustakaan. Teknik analisis data yang digunakan dalam penelitian ini adalah analisis kualitatif. Hasil dari penelitian ini adalah bahwa berdasarkan Undang-Undang Nomor 24 Tahun 2004 tentang Lembaga Penjamin Simpanan, perlindungan terhadap dana simpanan nasabah pada perbankan yang mengalami kepailitan dijamin oleh lembaga negara bernama Lembaga Penjamin Simpanan, bahkan hingga Rp2.000.000.000,- (dua miliar rupiah).
\end{abstract}




\title{
Kata kunci: Perbankan Pailit; Dana Simpanan Nasabah; Perlindungan Negara
}

\begin{abstract}
Bank is a financial institution whose business activities are collecting funds from the public, channeling funds to the public, and providing financial services. One of the main activities of banking is to collect funds from the public in the form of savings, time deposits and demand deposits. People save their funds in banks because they believe that the security of their funds will be much more secure than storing them at home. According to the Civil Code, customer funds deposited in a bank are not included in the privileged group of receivables when a bank is declared bankrupt. The problem that will be discussed in this research is how is the protection of the state against customer deposits in banks that experience bankruptcy? The method used in this research is normative legal research using a statutory approach. Sources of data used in this study is secondary data, namely data obtained from legislation, scientific journals, and legal literature. The data collection technique used in this research is literature study. The data analysis technique used in this research is qualitative analysis. The results of this study are that based on Law Number 24 of 2004 concerning the Deposit Insurance Corporation, the protection of customer deposits in banks experiencing bankruptcy is guaranteed by a state institution called the Deposit Insurance Corporation, even up to Rp2,000,000,000 (two billion rupiah). rupiah).
\end{abstract}

Keywords: Bankrupt Banking; Customer Deposit Funds; State Protection 


\section{PERLINDUNGAN NEGARA TERHADAP DANA SIMPANAN NASABAH PADA PERBANKAN - ANDREW SHANDY UTAMA, \& RAI IQSANDRI}

\section{PENDAHULUAN}

\section{Pendahuluan}

Di Indonesia, sebagaimana diamanatkan oleh Pancasila dan Undang-Undang Dasar Negara Republik Indonesia Tahun 1945, tujuan pembangunan nasional adalah terciptanya masyarakat adil dan makmur berdasarkan demokrasi ekonomi dengan mengembangkan sistem ekonomi yang berkeadilan. Untuk menjamin berlangsungnya demokrasi ekonomi, maka segala potensi, inisiatif, dan daya kreasi rakyat wajib dimobilisasikan dan dikembangkan sepenuhnya dalam batas-batas yang tidak merugikan kepentingan umum, sehingga dengan demikian, segala kekuatan ekonomi potensial dapat dikerahkan menjadi kekuatan ekonomi yang nyata bagi kemanfaatan peningkatan kemakmuran rakyat. Guna mencapai tujuan tersebut, maka pelaksanaan pembangunan ekonomi harus lebih memperhatikan keselarasan, keserasian, dan keseimbangan unsur-unsur pemerataan pembangunan, pertumbuhan ekonomi, dan stabilitas nasional. Salah satu lembaga yang mempunyai peran strategis dalam menyerasikan, menyelaraskan, dan menyeimbangkan masing-masing unsur dari trilogi pembangunan tersebut adalah perbankan.

Perbankan adalah segala sesuatu yang menyangkut tentang bank, mencakup kelembagaan, kegiatan usaha, serta cara dan proses dalam melaksanakan kegiatan usahanya. Lembaga perbankan sudah ada di Indonesia jauh sebelum negara ini merdeka. Kegiatan perbankan mulai diperkenalkan sejak zaman VOC (Vereenigde Oost-Indische Compagnie) menjajah Indonesia. VOC menggunakan sistem keuangan dan mekanisme pembayaran tersendiri dalam kegiatan perdagangannya. Oleh karena itu, pada tahun 1746, VOC mendirikan De Bank van Leening, yang kemudian diubah menjadi De Bank Courant en Bank van Leening pada tahun 1752. Bank ini adalah bank pertama yang lahir di Indonesia. ${ }^{1}$ Setelah itu, berdirilah Nederlandsche Handel Maatschappij pada tahun 1824, De Javasche Bank pada tahun 1828, NV Escompto Bank pada tahun 1857, Post Spaarbank pada tahun 1898, dan De Algemeene Volkscredit Bank pada tahun $1934 .^{2}$

Secara sederhara, bank diartikan sebagai lembaga keuangan yang kegiatan usahanya adalah menghimpun dana dari masyarakat dan menyalurkan kembali dana tersebut ke

\footnotetext{
${ }^{1}$ Muhamad Djumhana, Asas-asas Hukum Perbankan Indonesia (Citra Aditya Bakti 2008).[1].

${ }^{2}$ Djoni S. Gazali dan Rachmadi Usman, Hukum Perbankan (Sinar Grafika 2012).[146].
} 
masyarakat, serta memberikan jasa-jasa bank lainnya. ${ }^{3}$ Dari pengertian di atas, diketahui bahwa fungsi bank adalah sebagai lembaga penghimpun dan penyalur dana serta pelayanan jasa.

Menurut Pasal 3 Undang-Undang Nomor 7 Tahun 1992, fungsi utama perbankan Indonesia adalah sebagai penghimpun dan penyalur dana masyarakat. ${ }^{4}$ Pertama, bank berfungsi menghimpun dana dari masyarakat. Bank menghimpun dana dari masyarakat dalam bentuk simpanan. Masyarakat mempercayai bank sebagai tempat yang aman untuk melakukan investasi dan menyimpan dana. Masyarakat yang kelebihan dana sangat membutuhkan keberadaan bank untuk menyimpan dananya dengan aman. Keamanan atas dana yang disimpannya di bank oleh masyarakat merupakan faktor yang sangat penting bagi masyarakat. Selain rasa aman, tujuan lainnya adalah sebagai tempat untuk melakukan investasi. Masyarakat akan merasa lebih aman apabila uangnya diinvestasikan di bank. Dengan menyimpan uangnya di bank, nasabah juga akan mendapatkan keuntungan berupa return atas simpanannya yang besarnya tergantung kebijakan masing-masing bank. ${ }^{5}$

Kedua, bank berfungsi menyalurkan dana kepada masyarakat. Menyalurkan dana merupakan aktivitas yang sangat penting bagi bank karena bank akan memperoleh pendapatan atas dana yang disalurkan. Pendapatan yang diperoleh dari aktivitas penyaluran dana kepada nasabah merupakan pendapatan yang terbesar di setiap bank, sehingga penyaluran dana kepada masyarakat menjadi sangat penting bagi bank. Kegiatan penyaluran dana kepada masyarakat, di samping merupakan aktivitas yang dapat menghasilkan keuntungan, juga untuk memanfaatkan idle fund karena bank telah membayar sejumlah tertentu atas dana yang telah dihimpunnya. Dengan demikian, bank tidak boleh membiarkan dana masyarakat tersebut mengendap, dan harus segera menyalurkannya kepada masyarakat yang membutuhkan agar memperoleh pendapatan atas dana yang disalurkannya. Kredit yang diberikan kepada masyarakat menempati porsi aset yang terbesar di setiap bank. ${ }^{6}$

Memperhatikan peranan lembaga perbankan yang demikian strategis dalam mencapai tujuan pembangunan nasional, maka terhadap lembaga perbankan perlu senantiasa terdapat pembinaan dan pengawasan yang efektif, dengan didasari oleh landasan gerak yang kokoh agar lembaga perbankan di Indonesia mampu berfungsi secara efisien, sehat, wajar, dan

\footnotetext{
${ }^{3}$ Kasmir, Dasar-dasar Perbankan (Rajawali Pers 2012).[3].

${ }^{4}$ Undang-Undang Nomor 7 Tahun 1992 tentang Perbankan.

${ }^{5}$ Ismail, Manajemen Perbankan; Dari Teori Menuju Aplikasi (Kencana 2011).[4-5].

${ }^{6}$ Ismail, Manajemen Perbankan; Dari Teori Menuju Aplikasi (Kencana 2011).[5-6].
} 


\section{PERLINDUNGAN NEGARA TERHADAP DANA SIMPANAN NASABAH PADA PERBANKAN - ANDREW SHANDY UTAMA, \& RAI IQSANDRI}

mampu menghadapi persaingan yang semakin bersifat global, mampu melindungi secara baik dana yang dititipkan masyarakat kepadanya, serta mampu menyalurkan dana masyarakat tersebut ke bidang-bidang yang produktif bagi pencapaian sasaran pembangunan.

Sejalan dengan itu, undang-undang telah mengamanatkan bahwa setiap bank wajib memelihara tingkat kesehatanya sesuai dengan ketentuan kecukupan modal, kualitas aset, kualitas manajemen, likuiditas, rentabilitas, solvabilitas, dan aspek lain yang berhubungan dengan usaha bank, serta wajib melakukan kegiatan usaha sesuai dengan prinsip kehatihatian.

Bank dalam kegiatan operasionalnya harus menerapkan prinsip kehati-hatian (prudential banking principle). Prinsip kehati-hatian dalam mengelola dan menjalankan aktivitas perbankan sehari-hari bertujuan untuk menjaga kesehatan bank. Hal ini harus dilakukan mengingat bank merupakan lembaga kepercayaan masyarakat dan berfungsi untuk menjaga kestabilan moneter suatu negara melalui transaksi keuangan yang sehat pada perbankan.7

Kepercayaan masyarakat merupakan kata kunci utama bagi berkembang atau tidaknya suatu bank, dalam arti tanpa adanya kepercayaan dari masyarakat, suatu bank tidak akan mampu menjalankan kegiatan usahanya. ${ }^{8}$ Artinya, dalam memberikan kredit dan melakukan kegiatan usaha lainnya, setiap bank wajib menempuh cara-cara yang tidak merugikan bank dan kepentingan nasabah yang mempercayakan dananya kepada bank. Hal ini dikarenakan mengingat bank terutama bekerja dengan dana dari masyarakat yang disimpan pada bank atas dasar kepercayaan, maka setiap bank perlu terus menjaga kesehatannya dan memelihara kepercayaan masyarakat padanya.

Bank yang tidak sehat bukan hanya membahayakan dirinya sendiri, tetapi juga membahayakan pihak lain. Hal ini dikarenakan bank mengelola dana masyarakat yang dipercayakan kepadanya dalam bentuk tabungan, deposito, dan giro. Masyarakat sebagai pemilik dana dapat saja menarik simpanannya kapanpun jika mengetahui bank yang menjadi tempat ia menyimpan dana dalam keadaan tidak sehat. Perlu diketahui, tujuan utama masyarakat menyimpan dananya di bank adalah karena keamanan dananya terjamin, sedangkan tujuan lainnya adalah untuk berinvestasi, dengan harapan akan memperoleh

\footnotetext{
${ }^{7}$ Toto Octaviano Dendhana, 'Penerapan Prudential Banking Principle dalam Upaya Perlindungan Hukum bagi Nasabah Penyimpan Dana' (2013) I Jurnal Lex et Societatis.[52].

${ }^{8}$ Hermansyah, Hukum Perbankan Nasional Indonesia (Kencana 2006).[5].
} 
bunga dari simpanannya tersebut. Pada prinsipnya, hubungan antara bank dengan nasabah yang menyimpan dananya di bank dilandasi oleh hubungan saling percaya, sehingga setiap bank dituntut harus terus menjaga tingkat kesehatannya.

Berdasarkan uraian di atas, maka permasalahan yang akan dibahas dalam penelitian ini adalah bagaimanakah perlindungan negara terhadap dana simpanan nasabah pada perbankan yang mengalami kepailitan?

\section{Metode Penelitian}

Metode yang digunakan dalam penelitian ini adalah penelitian hukum normatif dengan menggunakan pendekatan peraturan perundang-undangan. Sumber data yang digunakan dalam penelitian ini adalah data sekunder, yaitu data yang diperoleh dari peraturan perundang-undangan, jurnal-jurnal ilmiah, dan literatur hukum. Teknik pengumpulan data yang digunakan dalam penelitian ini adalah studi kepustakaan. Teknik analisis data yang digunakan dalam penelitian ini adalah analisis kualitatif.

\section{Pembahasan}

Industri perbankan merupakan salah satu komponen yang sangat penting dalam perekonomian nasional demi menjaga keseimbangan, kemajuan, dan kesatuan ekonomi nasional. Stabilitas industri perbankan dimaksud sangat mempengaruhi stabilitas perekonomian secara keseluruhan, sebagaimana pengalaman yang pernah terjadi pada saat krisis moneter dan krisis perbankan di Indonesia pada tahun 1998 silam. Kepercayaan masyarakat terhadap industri perbankan nasional merupakan salah satu kunci untuk memelihara stabilitas industri perbankan, sehingga krisis tersebut tidak akan terulang lagi di masa yang akan datang. Kepercayaan ini dapat diperoleh dengan adanya kepastian hukum dalam pengaturan dan pengawasan bank serta penjaminan simpanan nasabah bank untuk meningkatkan kelangsungan usaha bank secara sehat.

Pada Pasal 37B Undang-Undang Nomor 10 Tahun 1998 disebutkan bahwa setiap bank wajib menjamin dana masyarakat yang disimpan pada bank yang bersangkutan. ${ }^{9}$

Sebenarnya, industri perbankan merupakan salah satu sektor yang paling kompleks regulasinya. Hal ini dikarenakan perbankan adalah badan hukum privat yang mengelola

\footnotetext{
${ }^{9}$ Undang-Undang Nomor 10 Tahun 1998 tentang Perubahan atas Undang-Undang Nomor 7 Tahun 1992 tentang Perbankan.
}

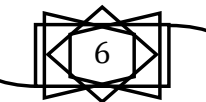




\section{PERLINDUNGAN NEGARA TERHADAP DANA SIMPANAN NASABAH PADA PERBANKAN - ANDREW SHANDY UTAMA, \& RAI IQSANDRI}

keuangan, terutama uang masyarakat yang dititipkan padanya. Akan tetapi, hukum pada kenyataannya seringkali ketinggalan dengan perkembangan yang terjadi di masyarakat, apalagi perkembangan di dunia bisnis seperti perbankan. Selalu ada celah hukum bagi pelaku usaha untuk mencari keuntungan yang sebesar-besarnya. Padahal, di dalam undang-undang selalu diatur dengan tegas mengenai sanksi pidana bagi yang melanggarnya.

Pada Pasal 49 Ayat (2) Undang-Undang Nomor 10 Tahun 1998 ditegaskan bahwa anggota dewan komisaris, direksi, atau pegawai bank yang dengan sengaja tidak melaksanakan langkah-langkah yang diperlukan untuk memastikan ketaatan bank terhadap ketentuan di dalam Undang-Undang Perbankan dan ketentuan peraturan perundangundangan lainnya yang berlaku bagi bank, diancam dengan pidana penjara sekurangkurangnya 3 (tiga) tahun dan paling lama 8 (delapan) tahun, serta denda sekurang-kurangnya Rp5.000.000.000,- (lima miliar rupiah) dan paling banyak Rp100.000.000.000,- (seratus miliar rupiah). ${ }^{10}$

Kelangsungan usaha bank secara sehat dapat menjamin keamanan simpanan para nasabahnya, serta meningkatkan peran bank sebagai penyedia dana pembangunan dan pelayanan jasa perbankan. Apabila bank kehilangan kepercayaan dari masyarakat sehingga kelangsungan usaha bank dimaksud tidak dapat dilanjutkan, maka bank tersebut akan menjadi bank gagal yang berakibat dicabut izin usahanya. Oleh karena itu, baik pemilik dan pengelola bank maupun berbagai otoritas yang terlibat dalam pengaturan dan/atau pengawasan bank harus bekerja sama mewujudkan kepercayaan masyarakat terhadap industri perbankan.

Bank gagal adalah bank yang mengalami kesulitan keuangan dan membahayakan kelangsungan usahanya serta dinyatakan tidak dapat lagi disehatkan oleh Lembaga Pengawas Perbankan sesuai dengan kewenangan yang dimilikinya.

Bank merupakan badan usaha yang memiliki karakteristik khusus, sehingga pencabutan izin usaha, pembubaran badan hukum, dan likuidasi sebuah bank tidak dapat dipersamakan dengan prosedur yang berlaku umum. Dalam situasi bank tidak dapat mengatasi kesulitannya atau keadaan bank yang bersangkutan membahayakan sistem perbankan nasional, maka diperlukan peran dari Bank Indonesia. Berdasarkan ketentuan pada Undang-Undang Perbankan, Bank Indonesia diberi kewenangan untuk mencabut izin usaha bank yang

${ }^{10}$ Undang-Undang Nomor 10 Tahun 1998 tentang Perubahan atas Undang-Undang Nomor 7 Tahun 1992 tentang Perbankan. 
bermasalah. Undang-Undang Kepailitan juga memberikan kewenangan kepada Bank Indonesia untuk mengajukan kepailitan terhadap bank yang bermasalah. ${ }^{11}$

Terhadap bank yang bermasalah, sebaiknya tidak dipailitkan menggunakan ketentuan yang ada menurut Undang-Undang Nomor 37 Tahun 2004 tentang Kepailitan dan Penundaan Kewajiban Pembayaran Utang. Adapun alasannya adalah karena proses likuidasi dan insolvensi yang diatur di dalam undang-undang tersebut tidak dapat diterapkan terhadap lembaga perbankan yang sudah memiliki aturan tentang proses likuidasi dan insolvensi tersendiri secara lebih rinci dan lengkap sebagai lex specialis. Hal ini karena lembaga perbankan tidak dapat disamakan dengan perusahaan pada umumnya. Selain itu, alasan tidak menggunakan ketentuan menurut Undang-Undang Kepailitan adalah karena peranan kurator dalam kepailitan bank akan menghilangkan peranan dan intervensi Bank Indonesia terhadap bank-bank bermasalah yang dinyatakan pailit, yang untuk penyelesaiannya membutuhkan keahlian khusus. Alasan selanjutnya adalah karena kepailitan lembaga perbankan dapat membahayakan posisi bank tersebut dan bank-bank lain. Terakhir, alasannya yaitu karena perlindungan terhadap kepentingan masyarakat penyimpan dana sebagai kreditor konkuren dalam hukum kepailitan menjadi tidak diutamakan, sehingga kepercayaan masyarakat luas terhadap lembaga perbankan menjadi berkurang. Hal ini akan berakibat lebih luas yang dapat mengganggu stabilitas keuangan negara. ${ }^{12}$

Untuk membubarkan sebuah perusahaan perbankan yang mengalami kepailitan tentunya tidak dapat dilakukan seketika itu juga, melainkan dibutuhkan tindakan-tindakan pemberesan, yang pastinya membutuhkan waktu untuk melakukannya. Masa tenggang waktu proses pemberesan inilah yang dinamakan proses likuidasi. Likuidasi bank merupakan tindakan yang sangat menyakitkan guna mengatasi bank yang sedang dalam kesulitan. Proses likuidasi itu sendiri merupakan langkah terakhir yang terpaksa dilakukan dengan pertimbangan bahwa kesulitan bank tersebut tidak saja dapat membahayakan kelangsungan hidup usahanya, tetapi sekaligus dapat menimbulkan systemic risk terhadap industri perbankan secara keseluruhan.

Likuidasi dalam kepailitan tidak berakibat langsung bubarnya suatu perusahaan. Bahkan, apabila kepailitan telah berakhir, perusahaan dapat hidup kembali dengan memenuhi

11 Ari Purwadi, 'Penerapan Ketentuan Kepailitan pada Bank yang Bermasalah' (2011) XVI Jurnal Perspektif.[128-139].

${ }^{12}$ Adrian Sutedi, Hukum Perbankan (Sinar Grafika 2007).[78].

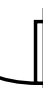




\section{PERLINDUNGAN NEGARA TERHADAP DANA SIMPANAN NASABAH PADA PERBANKAN - ANDREW SHANDY UTAMA, \& RAI IQSANDRI}

persyaratan setelah direhabilitasi. Hal yang demikian tidak mungkin dapat diterapkan terhadap lembaga perbankan, yang apabila izin usahanya dicabut dan bank tersebut dibubarkan, maka otomatis bank tidak dapat beroperasi lagi. Konsekuensi likuidasi bagi bank apabila menggunakan Undang-Undang Perbankan yaitu aset bank dicairkan semua dan dibagikan kepada para nasabah berdasarkan urutan prioritas.

Penanganan bank bermasalah dengan cara mencabut izin dan melikuidasinya sebaiknya dihindari. Alasannya adalah implikasi yuridis yang sangat kompleks dan proses penyelesaian yang memakan waktu lama. Selain itu, dapat mengguncangkan kepercayaan masyarakat terhadap sistem perbankan, serta likuidasi suatu bank dapat menimbulkan keresahan sosial di masyarakat dan implikasi yang sangat jauh. Hal tersebut sesuai dengan praktik perbankan negara-negara lain, dimana likuidasi bukan cara yang diminati. Berdasarkan laporan tahunan Bank for International Settlements (BIS) tahun 1993 disebutkan bahwa penyelamatan bank yang bermasalah di Amerika Serikat melalui likuidasi hanya 5,2\%.

Bank Indonesia, melalui mekanisme sistem pembayaran, akan mendeteksi bank yang mengalami kesulitan keuangan, dan dapat menjalankan fungsinya sebagai lender of last resort. Lembaga Pengawas Perbankan juga dapat mendeteksi kesulitan tersebut dan berupaya mengatasi dengan menjalankan fungsi pengawasannya, antara lain berupa tindakan agar pemilik bank menambah modal atau menjual bank, atau agar bank melakukan merger atau konsolidasi dengan bank lain. Apabila kondisi bank yang mengalami kesulitan keuangan tersebut semakin memburuk, antara lain ditandai dengan menurunnya tingkat solvabilitas bank, tindakan penyelesaian dan penanganan lain harus segera dilakukan.

Sehubungan dengan karakteristik lembaga perbankan yang mengelola dana masyarakat, apabila bank sebagai debitur berhubungan dengan soal kepailitan, maka pengajuan permohonan kepailitan tidak dapat diajukan sendiri oleh bank yang bersangkutan. Hal ini karena didasarkan alasan untuk mencegah agar kondisi seperti itu digunakan oleh pemegang saham atau pemilik bank guna berupaya untuk menghindarkan diri dari tanggung jawab terhadap para kreditur, termasuk nasabah penyimpan dana. Selanjutnya, apabila terjadi pencabutan izin usaha bank dan bank tersebut dilikuidasi, maka pembayaran atau pengembalian dana diutamakan kepada nasabah penyimpan dana daripada dengan kreditur konkuren lainnya, namun tetap dengan tidak mengabaikan pembayaran kewajiban kepada 
kreditur-kreditur yang harus diistimewakan berdasarkan peraturan perundang-undangan yang berlaku. ${ }^{13}$

Perlu diketahui, di dalam Bab 19 Kitab Undang-Undang Hukum Perdata diatur mengenai piutang-piutang yang diistimewakan atau didahulukan dalam pelunasannya. Berdasarkan ketentuan tersebut, maka dana nasabah yang disimpan di bank tidak termasuk piutang yang diistimewakan. Apabila suatu bank dilikuidasi, maka pemenuhan kewajiban diutamakan untuk pembayaran gaji pegawai dan pajak.

Dalam hal suatu bank dilikuidasi, seharusnya nasabah penyimpan dana didudukkan sebagai kreditor yang diutamakan (preferen) dengan tanpa mengabaikan pembayaran piutang kepada pihak-pihak lainnya. Hal ini dikarenakan sebagian besar sumber dana perbankan berasal dari simpanan yang dikumpul dari masyarakat. Dengan sendirinya, nasabah penyimpan dana mempunyai hak untuk menuntut kembali uang yang telah dipercayakannya untuk disimpan di bank. Hak preferen adalah suatu hak yang diberikan kepada kreditur untuk didahulukan dari kreditur-kreditur yang lain. Jadi, nasabah penyimpan yang harus didahulukan dalam menerima pembayaran dari bank yang sedang mengalami kegagalan atau kesulitan dalam memenuhi kewajiban-kewajibannya.

Dalam rangka memperoleh kembali dana yang disimpannya di bank, beserta bunganya apabila dimungkinkan, maka pada dasarnya nasabah merupakan pihak yang mendapat perhatian pertama untuk dibayar dari hasil penjualan harta kekayaan bank yang bersangkutan. Nasabah yang dirugikan oleh bank yang bermasalah dan dilikuidasi dapat meminta haknya dengan menggugat ke pengadilan, baik secara perorangan maupun gugatan kelompok.

Meskipun menurut Kitab Undang-Undang Hukum Perdata dana nasabah yang disimpan di bank bukan merupakan piutang yang diistimewakan, akan tetapi, pada saat krisis ekonomi tahun 1998 silam, Bank Indonesia langsung menunjuk tiga bank BUMN untuk membayarkan dana nasabah bank-bank yang dilikuidasi tersebut. Kepada nasabah penyimpan dana seperti penabung, giran, dan deposan akan dibayarkan jumlah simpanannya sampai dengan jumlah Rp20.000.000,- (dua puluh juta rupiah), yang merupakan dana talangan pemerintah. Hal ini menunjukkan adanya itikad baik dari pemerintah pada waktu itu, yang tidak ingin menyengsarakan rakyatnya. ${ }^{14}$

\footnotetext{
${ }^{13}$ Muhamad Djumhana, Hukum Perbankan di Indonesia (Citra Aditya Bakti 2003).[215].

${ }^{14}$ Djoni S. Gazali dan Rachmadi Usman, Hukum Perbankan (Sinar Grafika 2012).[568].
} 


\section{PERLINDUNGAN NEGARA TERHADAP DANA SIMPANAN NASABAH PADA PERBANKAN - ANDREW SHANDY UTAMA, \& RAI IQSANDRI}

Krisis perbankan yang terjadi di berbagai belahan dunia terjadi karena kurangnya independensi lembaga pengatur dan pengawas perbankan dari berbagai tekanan dan intervensi politik dari pemerintah. Hal ini mendorong menguatnya argumen bahwa pengaturan dan pengawasan bank sebaiknya memiliki independensi, baik dari pemerintah maupun dari dunia usaha. Faktor lain yang juga mendorong menguatnya argumen perlunya independensi pengaturan dan pengawasan bank adalah adanya kecenderungan dalam beberapa tahun terakhir untuk mengeluarkan fungsi pengawasan bank dari bank sentral serta membentuk lembaga tunggal yang independen yang mengatur dan mengawasi seluruh lembaga keuangan, baik bank maupun lembaga keuangan lainnya. ${ }^{15}$

Di Amerika Serikat, bentuk perlindungan bagi nasabah penyimpan dana sehubungan dengan penutupan suatu bank yang mengalami kegagalan, terutama deposan yang kecil, diciptakan suatu sistem asuransi deposito melalui Federal Deposit Insurance. Keruntuhan stock market Amerika Serikat pada tahun 1929 dan depresi akbar (great depression) telah melahirkan seperangkat peraturan perundang-undangan yang bertujuan untuk melibatkan pemerintah federal agar berperan lebih aktif dalam mengelola ekonomi negara. Di antara peraturan perundang-undangan tersebut adalah Banking Act of 1933 yang diberlakukan setelah ditutupnya 10.000 bank antara tahun 1929 sampai dengan tahun 1933. Penutupan begitu banyak bank tersebut tentu saja sangat merugikan nasabah-nasabah penyimpan dana dari bank-bank yang ditutup itu. Pada saat itu, nasabah dana yang dilindungi adalah nasabah yang mempunyai deposito tidak lebih dari $\$ 100.000$ (seratus ribu dollar). ${ }^{16}$

Misi Federal Deposit Insurance ini adalah memelihara stabilitas dari sistem keuangan negara dengan cara mengasuransikan para deposan bank dan mengurangi gangguangangguan terhadap ekonomi negara yang disebabkan karena kegagalan yang dialami oleh perbankan. Lembaga ini bertindak sebagai likuidator untuk bank-bank yang mengalami likuidasi dan memaksa agar standar-standar perbankan yang sehat dipatuhi melalui proses pemeriksaan. Berdasarkan penilaian, ternyata Federal Deposit Insurance merupakan skim yang sukses. Lembaga ini merupakan safety net bagi sistem keuangan di Amerika Serikat. ${ }^{17}$

Sementara itu, di Indonesia, pada saat krisis ekonomi tahun 1998, untuk mengembalikan kepercayaan masyarakat terhadap dunia perbankan dan sekaligus

\footnotetext{
${ }^{15}$ Ichsan Ferdinan S., 'Kewenangan Bank Indonesia Setelah Disahkan Undang-Undang Nomor 21 Tahun 2011 tentang Otoritas Jasa Keuangan' (2013) 2 Jurnal Privat Law.[5-6].

${ }^{16}$ Djoni S. Gazali dan Rachmadi Usman, Hukum Perbankan (Sinar Grafika 2012).[568].

${ }^{17}$ Djoni S. Gazali dan Rachmadi Usman, Hukum Perbankan (Sinar Grafika 2012).[568].
} 
melindungi hak-hak nasabah penyimpan dana, pemerintah mengeluarkan Keputusan Presiden Nomor 26 Tahun 1998 tentang Jaminan terhadap Kewajiban Pembayaran Bank Umum, yang pada intinya memberi perlindungan hukum secara langsung kepada nasabah penyimpan dana terhadap kegagalan bank dalam memenuhi kewajibannya. Perlindungan hukum terhadap nasabah bank diatur secara implisit dan eksplisit dalam sistem hukum perbankan di Indonesia. ${ }^{18}$

Sebelum dikeluarkannya Keputusan Presiden Nomor 26 Tahun 1998, perlindungan terhadap nasabah sangat minim dalam badan hukum perbankan Indonesia. Dalam hal pencabutan izin usaha bank yang diikuti dengan proses likuidasi menjadikan kedudukan nasabah untuk mendapatkan uangnya kembali baru dapat diberikan dalam jumlah yang ditetapkan oleh Tim Likuidasi, itupun setelah gaji pegawai yang terutang, pajak yang terutang, dan biaya kantor. Kenyataan ini lebih diperparah lagi dengan lambatnya proses likuidasi bank. Artinya, selain kedudukan yang tidak terlindungi secara memadai, pengambilan uang nasabah umumnya memakan waktu lama.

Dengan dikeluarkannya Keputusan Presiden Nomor 26 Tahun 1998 tersebut, kedudukan nasabah semakin membaik. Pemerintah melalui Badan Penyehatan Perbankan Nasional (BPPN) akan menalangi terlebih dahulu dana masyarakat yang disimpan di bank apabila bank tersebut tidak dapat membayar kewajibannya kepada nasabah.

Penjaminan seluruh kewajiban bank berdasarkan Keputusan Presiden di masa lalu tersebut, telah berhasil mewujudkan kepercayaan masyarakat terhadap industri perbankan pada masa krisis moneter dan krisis perbankan. Namun, penjaminan yang sangat luas ini juga membebani anggaran negara dan menimbulkan moral hazard pada pihak pengelola bank dan nasabah bank. Pengelola bank tidak terdorong untuk melakukan usaha bank secara prudent, sementara nasabah tidak memperhatikan atau mementingkan kondisi kesehatan bank dalam bertransaksi dengan bank.

Selain itu, penerapan penjaminan secara luas ini yang berdasarkan kepada Keputusan Presiden kurang dapat memberikan kekuatan hukum sehingga menimbulkan permasalahan dalam pelaksanaan penjaminan. Oleh karena itu, diperlukan dasar hukum yang lebih kuat dalam bentuk undang-undang. Untuk melindungi dana simpanan nasabah pada bank gagal yang mengalami kepailitan, maka pada tanggal 22 September 2004 disahkan Undang-Undang

${ }^{18}$ Jeanette Karundeng, 'Perlindungan Hukum Nasabah dalam Likuidasi Bank Menurut Undang-Undang Nomor 24 Tahun 2004 tentang Lembaga Penjamin Simpanan’ (2015) III Jurnal Lex et Societatis.[69]. 


\section{PERLINDUNGAN NEGARA TERHADAP DANA SIMPANAN NASABAH PADA PERBANKAN - ANDREW SHANDY UTAMA, \& RAI IQSANDRI}

Nomor 24 Tahun 2004 tentang Lembaga Penjamin Simpanan. Di dalam undang-undang ini, ditetapkan bahwa penjaminan simpanan nasabah bank diselenggarakan oleh Lembaga Penjamin Simpanan.

Lembaga Penjamin Simpanan adalah sebuah lembaga independen yang transparan dan akuntabel dalam menjalankan fungsinya, yaitu menjamin simpanan nasabah penyimpan dan turut aktif dalam memelihara stabilitas sistem perbankan sesuai dengan kewenangannya.

Setiap bank yang melakukan kegiatan usaha di wilayah Negara Republik Indonesia wajib menjadi peserta penjaminan oleh Lembaga Penjamin Simpanan. Kewajiban untuk mengikuti penjaminan tersebut berlaku pula bagi kantor cabang dari bank yang berkedudukan di luar negeri (bank asing) yang melakukan kegiatan perbankan di dalam wilayah Negara Republik Indonesia, sedangkan kantor cabang dari bank yang berkedudukan di Indonesia yang melakukan kegiatan perbankan di luar wilayah Negara Republik Indonesia (kantor cabang di luar negeri) tidak termasuk dalam penjaminan.

Pada Pasal 11 Ayat (1) Undang-Undang Nomor 24 Tahun 2004 disebutkan bahwa Lembaga Penjamin Simpanan menjamin simpanan nasabah bank yang berbentuk giro, deposito, sertifikat deposito, tabungan, dan/atau bentuk lainnya yang dipersamakan dengan itu. Nilai simpanan yang dijamin untuk setiap nasabah pada satu bank paling banyak Rp100.000.000,- (seratus juta rupiah). ${ }^{19}$

Penjaminan simpanan nasabah bank yang dilakukan oleh Lembaga Penjamin Simpanan bersifat terbatas, tetapi dapat mencakup sebanyak-banyaknya nasabah. Setiap bank yang menjalankan usahanya di Indonesia diwajibkan untuk menjadi peserta dan membayar premi penjaminan. Dalam hal bank tersebut tidak dapat melanjutkan usahanya dan harus dicabut izin usahanya, Lembaga Penjamin Simpanan akan membayar simpanan setiap nasabah bank tersebut sampai jumlah tertentu. Adapun simpanan yang tidak dijamin akan diselesaikan melalui proses likuidasi bank. Likuidasi ini merupakan tindak lanjut dalam penyelesaian bank yang mengalami kesulitan keuangan.

Beberapa ketentuan yang diatur dalam Undang-Undang Nomor 24 Tahun 2004 yang berkaitan dengan resolusi bank, termasuk ketentuan mengenai likuidasi bank, memberikan ruang yang terlalu luas terhadap penafsiran yang beragam yang menimbulkan potensi perbedaan pandangan di kalangan ahli hukum korporasi. Hal ini jelas akan melahirkan

\footnotetext{
${ }^{19}$ Undang-Undang Nomor 24 Tahun 2004 tentang Lembaga Penjamin Simpanan.
} 
kondisi yang tidak kondusif dalam melindungi kepentingan negara terkait dengan pelaksanaan fungsi, tugas, dan wewenang Lembaga Penjamin Simpanan di bidang penjaminan simpanan nasabah bank. ${ }^{20}$

Perlu diketahui, tindakan penyelesaian atau penanganan bank gagal didahului berbagai tindakan oleh Bank Indonesia dan Lembaga Pengawas Perbankan sesuai peraturan perundang-undangan. Apabila kondisi bank yang mengalami kesulitan keuangan tersebut semakin memburuk, antara lain ditandai dengan menurunnya tingkat solvabilitas bank, tindakan penyelesaian dan penanganan lain harus segera dilakukan. Dalam keadaan ini, penyelesaian dan penanganan terhadap bank gagal diserahkan kepada Lembaga Penjamin Simpanan yang akan bekerja setelah terlebih dahulu dipertimbangkan perkiraan dampak pencabutan izin usaha bank terhadap perekonomian nasional. Bank gagal yang akan diselamatkan ada yang tidak berdampak sistemik serta ada juga yang berdampak sistemik.

Berdasarkan Pasal 27 Undang-Undang Nomor 24 Tahun 2004, seluruh biaya penyelamatan bank yang dikeluarkan oleh Lembaga Penjamin Simpanan menjadi penyertaan modal sementara Lembaga Penjamin Simpanan pada bank tersebut. Lembaga Penjamin Simpanan wajib membayar klaim penjaminan kepada nasabah penyimpan dari bank yang dicabut izin usahanya. Dalam hal nasabah penyimpan pada saat yang bersamaan mempunyai kewajiban kepada bank, maka pembayaran klaim penjaminan dilakukan setelah kewajiban nasabah penyimpan kepada bank tersebut terlebih dahulu diperhitungkan berdasarkan peraturan perundang-undangan. ${ }^{21}$

Dengan adanya Lembaga Penjamin Simpanan yang berperan sebagai penjamin dana simpanan nasabah di bank, maka apabila terdapat bank yang mengalami kesulitan usaha, kemudian dicabut izin usahanya dan dilikuidasi, kedudukan nasabah bank adalah mengikuti Peraturan Pemerintah Nomor 25 Tahun 1999 tentang Pencabutan Izin Usaha, Pembubaran, dan Likuidasi Bank. Dalam hal ini, nasabah bank didahulukan pembayarannya dibandingkan dengan kreditor lainnya.

Jadi, lahirnya Lembaga Penjamin Simpanan merupakan angin segar dalam sistem perbankan di Indonesia. Nasabah yang mempercayakan uangnya disimpan di bank, baik dalam bentuk tabungan, deposito, dan giro, tidak perlu lagi khawatir akan keamanan

${ }^{20}$ Rizal Ramadhani, 'Likuidasi terhadap Bank yang Berbentuk Hukum Perusahaan Daerah; Suatu Upaya Perlindungan Hukum terhadap Kepentingan Lembaga Penjamin Simpanan dalam Pelaksanaan Program Penjaminan Simpanan' (2006) 4 Buletin Hukum Perbankan dan Kebanksentralan.[33].

${ }^{21}$ Undang-Undang Nomor 24 Tahun 2004 tentang Lembaga Penjamin Simpanan. 


\section{PERLINDUNGAN NEGARA TERHADAP DANA SIMPANAN NASABAH PADA PERBANKAN - ANDREW SHANDY UTAMA, \& RAI IQSANDRI}

simpanannya. Hal ini karena Lembaga Penjamin Simpanan menjamin keamanan simpanan nasabah tersebut yang ada di bank.

Apabila seorang nasabah memiliki beberapa rekening pada satu bank, maka untuk menghitung simpanan yang dijamin, saldo seluruh rekening tersebut dijumlahkan. Pembayaran atas klaim penjaminan wajib dilakukan oleh Lembaga Penjamin Simpanan kepada nasabah dari bank yang dicabut izin usahanya setelah dilakukan rekonsiliasi dan verifikasi atas data simpanan yang layak dibayar dan simpanan yang tidak layak bayar. ${ }^{22}$

Bahkan, sejak terjadinya krisis global pada tahun 2008, pemerintah kemudian mengeluarkan Perppu Nomor 3 Tahun 2008 tentang Perubahan Atas Undang-Undang Nomor 24 Tahun 2004 tentang Lembaga Penjamin Simpanan, yang intinya yaitu mengubah nilai simpanan yang dijamin oleh Lembaga Penjamin Simpanan menjadi Rp2.000.000.000,- (dua miliar rupiah).

Jadi, peran Lembaga Penjamin Simpanan adalah sebagai badan hukum yang menyelenggarakan kegiatan penjaminan atas simpanan nasabah penyimpan melalui skim asuransi, dana penyangga, atau skim lainnya. Besarnya nilai simpanan yang dijamin oleh Lembaga Penjamin Simpanan sampai dengan Rp2.000.000.000,- (dua miliar rupiah) pernasabah. ${ }^{23}$ Undang-Undang Nomor 24 Tahun 2004 tentang Lembaga Penjamin Simpanan adalah perlindungan hukum yang paling baik terhadap nasabah penyimpan. UndangUndangNomor 24 Tahun 2004 memberikan perlindungan hukum secara langsung terhadap penjaminan dana simpananan nasabah. ${ }^{24}$

\section{Kesimpulan}

Menurut Kitab Undang-Undang Hukum Perdata, dana nasabah yang disimpan di bank tidak termasuk ke dalam kelompok piutang yang diistimewakan apabila sebuah bank dinyatakan pailit. Meskipun demikian, pada saat krisis ekonomi dan krisis perbankan yang terjadi tahun 1998, pemerintah berani mengeluarkan Keputusan Presiden Nomor 26 Tahun 1998 untuk menjamin dana simpanan nasabah pada bank-bank yang dilikuidasi. Hal ini bertujuan untuk tetap menjaga kepercayaan masyarakat terhadap perbankan di Indonesia.

\footnotetext{
${ }^{22}$ Rilda Murniati, 'Perlindungan Hukum atas Dana Nasabah pada Bank Melalui Lembaga Penjamin Simpanan' (2013) 7 Jurnal Fiat Justitia.[315].

${ }^{23}$ Yennie Agustin M.R., 'Peran Lembaga Penjamin Simpanan terhadap Klaim Dana Nasabah Bank Likuidasi' (2013) 7 Jurnal Fiat Justitia.[324].

${ }^{24}$ Sarasdewi Febryanti, Hendro Saptono, dan Siti Mahmudah, 'Tanggung Jawab Lembaga Penjamin Simpanan terhadap Nasabah Penyimpan Bilyet Deposito Akibat Likuidasi Bank’ (2016) 5 Jurnal Diponegoro Law Review.[14].
} 
Setelah disahkannya Undang-Undang Nomor 24 Tahun 2004 tentang Lembaga Penjamin Simpanan, maka penjaminan simpanan nasabah bank diselenggarakan oleh Lembaga Penjamin Simpanan. Pada tahun 2008, pemerintah mengeluarkan Perppu Nomor 3 Tahun 2008 tentang Perubahan Atas Undang-Undang Nomor 24 Tahun 2004, yang intinya yaitu mengubah nilai simpanan yang dijamin oleh Lembaga Penjamin Simpanan menjadi Rp2.000.000.000,- (dua miliar rupiah). 


\section{PERLINDUNGAN NEGARA TERHADAP DANA SIMPANAN NASABAH PADA PERBANKAN - ANDREW SHANDY UTAMA, \& RAI IQSANDRI}

\section{Daftar Pustaka}

\section{Buku:}

Adrian Sutedi, Hukum Perbankan (Sinar Grafika 2007).

Djoni S. Gazali dan Rachmadi Usman, Hukum Perbankan (Sinar Grafika 2012).

Hermansyah, Hukum Perbankan Nasional Indonesia (Kencana 2006).

Ismail Manajemen Perbankan; Dari Teori Menuju Aplikasi (Kencana 2011).

Kasmir, Dasar-dasar Perbankan (Rajawali Pers 2012).

Muhamad Djumhana, Hukum Perbankan di Indonesia (Citra Aditya Bakti 2003).

Muhamad Djumhana, Asas-asas Hukum Perbankan Indonesia (Citra Aditya Bakti 2008).

Jurnal:

Ari Purwadi, 'Penerapan Ketentuan Kepailitan pada Bank yang Bermasalah' (2011) XVI Jurnal Perspektif.

Ichsan Ferdinan S., 'Kewenangan Bank Indonesia Setelah Disahkan Undang-Undang Nomor 21 Tahun 2011 tentang Otoritas Jasa Keuangan' (2013) 2 Jurnal Privat Law.

Jeanette Karundeng, 'Perlindungan Hukum Nasabah dalam Likuidasi Bank Menurut UndangUndang Nomor 24 Tahun 2004 tentang Lembaga Penjamin Simpanan' (2015) III Jurnal Lex et Societatis.

Rilda Murniati, 'Perlindungan Hukum atas Dana Nasabah pada Bank Melalui Lembaga Penjamin Simpanan' (2013) 7 Jurnal Fiat Justitia.

Rizal Ramadhani, 'Likuidasi terhadap Bank yang Berbentuk Hukum Perusahaan Daerah; Suatu Upaya Perlindungan Hukum terhadap Kepentingan Lembaga Penjamin Simpanan dalam Pelaksanaan Program Penjaminan Simpanan' (2006) 4 Buletin Hukum Perbankan dan Kebanksentralan.

Sarasdewi Febryanti, Hendro Saptono, dan Siti Mahmudah, 'Tanggung Jawab Lembaga Penjamin Simpanan terhadap Nasabah Penyimpan Bilyet Deposito Akibat Likuidasi Bank' (2016) 5 Jurnal Diponegoro Law Review.

Toto Octaviano Dendhana, 'Penerapan Prudential Banking Principle dalam Upaya Perlindungan Hukum bagi Nasabah Penyimpan Dana' (2013) I Jurnal Lex et Societatis.

Yennie Agustin M.R., 'Peran Lembaga Penjamin Simpanan terhadap Klaim Dana Nasabah Bank Likuidasi' (2013) 7 Jurnal Fiat Justitia. 


\section{Perundang-undangan:}

Undang-Undang Nomor 7 Tahun 1992 tentang Perbankan (Lembaran Negara Republik Indonesia Tahun 1992 Nomor 31, Tambahan Lembaran Negara Republik Indonesia Nomor 3472).

Undang-Undang Nomor 10 Tahun 1998 tentang Perubahan atas Undang-Undang Nomor 7 Tahun 1992 tentang Perbankan (Lembaran Negara Republik Indonesia Tahun 1998 Nomor 182, Tambahan Lembaran Negara Republik Indonesia Nomor 3790).

Undang-Undang Nomor 24 Tahun 2004 tentang Lembaga Penjamin Simpanan (Lembaran Negara Republik Indonesia Tahun 2004 Nomor 96, Tambahan Lembaran Negara Republik Indonesia Nomor 4420). 